\title{
Sooty blotch and flyspeck control with fungicide applications based on calendar, local IPM, and warning system
}

\author{
Piérri Spolti(1), Rosa Maria Valdebenito-Sanhueza(2), Mark Lawrence Gleason ${ }^{(3)}$ \\ and Emerson Medeiros Del Ponte ${ }^{(1)}$
}

\begin{abstract}
(1)Universidade Federal do Rio Grande do Sul, Faculdade de Agronomia, Departamento de Fitossanidade, Avenida Bento Gonçalves, no 7712 , CEP 91540-000 Porto Alegre, RS, Brazil. E-mail: pierrispolti@gmail.com, emerson.delponte@ufrgs.br (2)Proterra Engenharia Agronômica Ltda., BR-116, no 7320, CEP 95200-000 Vacaria, RS, Brazil. E-mail: rosamaria@m2net.com.br (3)lowa State University, Department of Plant Pathology, no 50011, Ames, IA, US. E-mail: mgleason@iastate.edu
\end{abstract}

\begin{abstract}
The objective of this work was to compare fungicide application timing for the control of sooty blotch and flyspeck (SBFS) of 'Fuji' apples in Rio Grande do Sul state, Brazil. The following treatments were evaluated in two growing seasons: two warning system-based (modified version of the Brown-Sutton-Hartmann system) spray of captan plus thiophanate methyl, with or without summer pruning; two calendar/rain-based spray of captan or a mixture of captan plus thiophanate methyl; fungicide spray timing based on a local integrated pest management (IPM) for the control of summer diseases; and a check without spraying. Sooty blotch and flyspeck incidence over time and their severity at harvest were evaluated. The highest number of spray was required by calendar/rain-based treatments (eight and seven sprays in the sequential years). The warning system recommended five and three sprays, in the sequential years, which led to the highest SBFS control efficacy expressed by the reduced initial inoculum and disease progress rate. Summer pruning enhanced SBFS control efficacy, especially by suppressing SBFS signs which tended to be restrained to the peduncle region of the fruit. Sooty blotch and flyspeck can be managed both with calendar and the grower-based IPM practices in Brazil, but a reduced number of sprays is required when the warning system is used.
\end{abstract}

Index terms: Malus domestica, disease forecasting, fungicide management, integrated pest managemet.

\section{Controle de fuligem e sujeira-de-mosca com aplicações de fungicidas baseadas em calendário, MIP local e sistema de alerta}

Resumo - O objetivo deste trabalho foi comparar épocas de aplicação de fungicida para o controle da fuligem e sujeira-de-mosca (FSM) em maçãs 'Fuji' no Estado do Rio Grande do Sul. Foram avaliados os seguintes tratamentos em dois ciclos de produção: dois baseados em sistema de previsão (modificação do sistema Brown-Sutton-Hartmann), com aplicação de captan em mistura com tiofanato metílico, com ou sem poda de verão; dois baseados em calendário ou ocorrência de chuva, com aplicação de captan ou mistura deste com tiofanato metílico; aplicação de fungicidas com base no manejo integrado de pragas (MIP) local para o controle de doenças de verão; e testemunha sem aplicação de fungicida. A incidência de FSM foi avaliada ao longo do tempo, e a severidade, na colheita. O maior número de aplicações (oito e sete em anos sequenciais) foi necessário nos tratamentos com recomendação de aplicação baseada no calendário. O sistema de previsão recomendou cinco e três aplicações, o que levou à maior eficiência de controle de FSM, pela redução de inóculo e da taxa de progresso da doença. A poda de verão incrementou a eficácia do controle da doença, especialmente pela restrição dos sinais de FSM na região peduncular do fruto. A FSM pode ser controlada tanto com o método do calendário, quanto com o uso das práticas de MIP com manejo local, mas o controle baseado no sistema de previsão requer menor número de aplicações.

Termos para indexação: Malus domestica, previsão de doença, manejo de fungicidas, manejo integrado de doenças.

\section{Introduction}

Sooty blotch and flyspeck (SBFS) of apples (Malus domestica Borkh.) is caused by a complex of fungal species (Díaz Arias et al., 2010) which blemishes the epicuticular wax layer of fruit (Williamson \& Sutton, 2000; Batzer et al., 2005). In the United States,
SBFS epidemics may lead to downgrading fruit from premium fresh-market grade to processing use (Sutton \& Sutton, 1994; Williamson \& Sutton, 2000). In the Southern Hemisphere, SBFS was first reported in the late 1980s (Berton \& Melzer, 1989), but its etiology is still not well understood. 
Infection timing and spatial SBFS patterns have been investigated recently in apples, in Rio Grande do Sul state (Spolti et al., 2011b). In Brazil, SBFS is most common and of greatest concern in organic production systems (Valdebenito-Sanhueza et al., 2008). Nevertheless, recent survey data in commercial orchards, from different production regions of the country, showed increasing levels of SBFS epidemics, and SBFS signs appeared most frequently in the peduncle, possibly because of deficient fungicide cover on this fruit part (Spolti et al., 2011a).

Sooty blotch and flyspeck studies on apple, in the last century, have focused mostly on the etiology and symptomatology (Sutton \& Sutton, 1994; Batzer et al., 2005; Díaz Arias et al., 2010), inoculum sources, timing of initial infections and favorable environmental conditions for the disease (Brown \& Sutton, 1993; Cooley et al., 2007), cultivar susceptibility (Belding et al., 2000), and management strategies based on chemical and cultural practices (Ocamb-Basu et al., 1988; Brown \& Sutton, 1995; Rosenberger et al., 1996; Duttweiler et al., 2008). However, there is a lack of data describing the temporal dynamics of SBFS epidemics which could inform more cost-effective management practices.

In order to prevent economic losses from SBFS, protectant fungicide spray programs are often recommended (Brown \& Sutton, 1993), and the most common strategy is based on applications of captan plus thiophanate-methyl. However, calendar-based fungicide spray programs for SBFS are costly and show potential health risks to applicators and consumers. No specific criteria have been developed for controlling SBFS in Brazil, and although protectant fungicide sprays are used for managing fruit rots, relatively high SBFS incidence can be found in years favorable for the disease (Spolti, 2011b).

Disease-warning systems may help growers to decide when to apply fungicide sprays based on the risk of economic loss. In North Carolina, USA, Brown \& Sutton (1995) reported cumulative hours of leaf wetness duration(LWD) to timing of appearance of the first SBFS signs on apples. The original and modified versions of this system (named the Brown-Sutton-Hartman system) were validated in field trials across North American production regions during the late 1990s (Williamson \& Sutton, 2000; Babadoost et al., 2004; Duttweiler et al., 2008). The Brown-Sutton-Hartmann system has helped growers to reduce the frequency of sprays in apple orchards, but results have sometimes been inconsistent (Babadoost et al., 2004). Differences in both climate and the assemblage of species causing SBFS complex, across production regions, emphasize caution when transferring empirically-derived SBFS warning system rules to other apple regions (Gleason et al., 2011). Therefore, region-specific evaluation is necessary before wide adoption by growers be recommended (Duttweiller et al., 2008). The Brown-Sutton-Hartman system, developed in North Carolina and modified in Kentucky, predicts timing of the first appearance of SBFS based on accumulated hours of LWD. The model recommends the application of the second-cover fungicide spray after 175-hour LWD, and that additional sprays should follow a fixed calendar (Brown \& Sutton, 1995).

In Brazil, disease-warning systems have been used for over two decades to aid tactical decisions in helping to create a more rational management of apple diseases (Berton \& Melzer, 1989; Pavan et al., 2006). However, SBFS warning systems have not been adapted to Brazilian conditions.

The objective of this work was to evaluate methods for fungicide application timing and the Brown-Sutton-Hartman system to guide fungicide application and provide an acceptable control of SBFS.

\section{Materials and Methods}

The experiments were carried out during 2006/2007 and 2007/2008 growing seasons, with the apple cultivar grafted onto MM-106 rootstock, in an orchard located at Vacaria, RS, Brazil, at $28^{\circ} 29^{\prime} 45^{\prime \prime} \mathrm{S}$ and $50^{\circ} 50^{\prime} 20^{\prime \prime} \mathrm{W}$. The orchard was established in 1988 with $5 \mathrm{~m}$ between rows, and $2 \mathrm{~m}$ within rows with a $6 \mathrm{~m}^{3}$ canopy. During the experimental period, insecticides and miticides were applied according to integrated pest management (IPM) recommendations for the region (Valdebenito-Sanhueza et al., 2008).

Rainfall $(\mathrm{mm})$, temperature $\left({ }^{\circ} \mathrm{C}\right)$, relative humidity (\%) and LWD (hour) were recorded hourly by a datalogger Adcon A730SEN (Adcon Telemetry, Klosterneuburg, Austria). Leaf wetness duration sensors and temperature sensors were placed within the tree canopy at $1.5 \mathrm{~m}$ height. They were not painted and were south-oriented facing at a $45^{\circ}$ angle. 
Two significant modifications in the Brown-Sutton-Hartman system were made. First, computations of the 175-hour LWD threshold began on the $15^{\text {th }}$ day after petal, and the preceding fungicide spray was made based on the grower's calendar for apple scab control. Second, the use of the LWD threshold was extended to apply sequential sprays after the spray at the initial 175-hour threshold. Hence, sequential fungicide sprays followed the same rule, that is, a spray was delayed until a second LWD threshold (175-hour) was reached (Trapman, 2004). Daily LWD was accumulated over time using a decision rule which excluded wetting periods of less than four hours (Brown \& Sutton, 1995).

Five treatments were conducted in 2006/2007, and six treatments in 2007/08 (Table 1). In each year, two warning system-based treatments utilized captan plus thiophanate-methyl (120 g $49 \mathrm{~g}$ a.i.) with or without summer pruning. The use of summer pruning was carried out to promote more rapid dry off and better penetration of pesticide spray (Cooley et al., 1997). Summer pruning was made during the last week of February for both seasons.

The two calendar/rain treatments consisted of either captan plus the surfactant Ag-Bem at $1 \mathrm{~mL} \mathrm{~L}^{-1}$ (Dow AgroSciences Industrial Ltda., São Paulo, SP) or a mixture of captan plus thiophanate-methyl (120 g +49 g a.i.) (in 2007/2008 only), reapplied at a 14-day interval or after $50 \mathrm{~mm}$ rain has accumulated, whichever threshold occurred first. Dates of spray were: 6 and 20 December, 3, 6, 12, and 25 January, 6 and 26 February, 7, 12, and 22 March for 2006/2007 season; and 19 and 17 December, 10 and
21 January, 7, 15 and 21 February, 6 and 20 March for 2007/2008 season.

A first control treatment, named "local IPM", consisted of fungicide spray timing based on local decision rules for fruit rot management (Pavan et al., 2006). The fungicides (dose a.i. $100 \mathrm{~L}^{-1}$ ) utilized by the grower during the two seasons were: thiophanate-methyl plus potassium phosphite $(4.9 \mathrm{~g}+$ $300 \mathrm{~mL})$, thiophanate-methyl plus captan $(4.9 \mathrm{~g}+120 \mathrm{~g})$, mancozeb (160 g) and mancozeb plus chlorothalonil $(160 \mathrm{~g}+123 \mathrm{~g})$. Dates of spray were: December 7, 15 and 20, January 3 and 15, February 8 and 17, March 7 for 2006/2007 season; and December 20, January 4, 11 and 22, February 8 and 18, and March 13 for 2007/2008 season. A second control was an unsprayed treatment.

The experiments were conducted using a randomized complete block design with five replicates. Each replicate consisted of a 5-tree subplot, in which the central three trees of each subplot were evaluated. Fungicides were applied using a backpack hand-pump sprayer in a volume of $1 \mathrm{~L}$ per tree.

Twenty-five shoots at mid-height $(1.2-1.75 \mathrm{~m})$ of each tree were marked, and all fruit on these shoots (245 to 456 per tree) were observed twice a week from the day in which disease signs were first visually detected by the naked eye in the non-sprayed check. These fruit were evaluated for SBFS incidence (proportion of affected fruit in the sample). At harvest, a 75-fruit sample was arbitrarily collected across the experimental plots. In the laboratory, SBFS incidence was estimated visually, and it was observed whether signs were restricted to a specific parts of the fruit: peduncle $(\mathrm{P})$; equatorial part

Table 1. Treatment information and number of sprays for the control of sooty blotch and flyspeck in a commercial 'Fuji' apple orchard in Southern Brazil, during 2006/2007 and 2007/2008 crop cycles.

\begin{tabular}{lccc}
\hline Treatment ${ }^{(1)}$ & Fungicide & \multicolumn{2}{c}{ Number of sprays } \\
\cline { 3 - 4 } & & $2006 / 2007$ & $2007 / 2008$ \\
\hline Unsprayed & None & 0 & 0 \\
Local IPM & Various & 8 & 7 \\
Calendar/rainfall (cap) & Captan & 11 & 9 \\
Calendar/rainfall (cap+tm) & Captan + thiophanate-methyl & - & 9 \\
Warning system / pruning & Captan + thiophanate-methyl & 5 & 3 \\
Warning system / no pruning & Captan + thiophanate-methyl & 5 & 3 \\
\hline
\end{tabular}

(1)Unsprayed, no fungicide; local IPM, grower`s decision based on the integrated pest management (IPM) rules and on a local disease warning system for fruit rots; calendar/rainfall (cap), application of captan plus Ag-Bem every 14 days or after accumulation of $50 \mathrm{~mm}$ of rain, whichever occurred first; calendar/rainfall (cap $+\mathrm{tm})$, same as previous, but using thiophanate-methyl plus captan; warning system/pruning, modified BrownSutton-Hartmann system - first spray after 175-hour leaf wetness duration (LWD) threshold, reached after the 15th day after petal fall, and further sprays delayed until a following LWD threshold was reached - and summer pruning; warning system/no pruning, same as previous, but without summer pruning, captan, $120 \mathrm{~g}$ a.i., thiophanate-methyl, $49 \mathrm{~g}$ a.i. 
(E); and calyx end (C). Further assessments were made for situations of presence of disease signs in more than one of those regions. Disease severity (percentage of fruit portion covered by symptoms) was visually estimated in the same sample for each of the three fruit portions described above. Severity scores were given according to six classes of severity: 1,0 to $3 \% ; 2,3$ to $6 \% ; 3,6$ to $12 \% ; 4,12$ to $25 \% ; 5,25$ to $50 \%$; and 6 to $>50 \%)$.

To evaluate the effect of treatments on different aspects of the epidemics, population dynamic models (monomolecular or logistic) were fit to the progress curves of SBFS incidence, by using linear regression for the model-transformed incidence values against time. Choice of the model was based on graphs of residuals and statistical parameters (Madden et al., 2007). Three model parameters - initial inoculum $\left(\mathrm{y}_{0}\right)$, apparent infection rate (r) and final incidence $\left(\mathrm{y}_{\mathrm{F}}\right)-$ were compared among treatments in a growing season, and the area under the disease progress curve (AUDPC) for the cumulative SBFS incidence was also estimated (Madden et al., 2007). Means for the model parameters fitted to the data were separated by least significance difference (LSD) at 5\% probability.

For the severity data, fixed effects included treatments and fruit region, while random effects included blocks. Fixed effects were considered significant at $5 \%$ probability unless otherwise stated. Least square means of treatments were compared using the Pdiff options in the LSMeans statement of the SAS Proc Mixed (SAS Institute, Cary, NC), and LSD values were calculated using the standard errors, with $t$ values representing the adjusted degrees of freedom. When interactions were significant, the LSD for main effects was further adjusted by including the interaction in the random statement.

\section{Results and Discussion}

First signs of the disease, mainly of the fuliginous mycelial type, were observed on March 3, 2007 and February 22, 2008, 120 and 123 days after petal fall, respectively.

Although SBFS is considered a disease of minor importance for commercial production in Brazil, relatively high incidence levels were observed even in the fungicide-protected fruit (Figure 1). When the disease was visually detected in the non-sprayed check

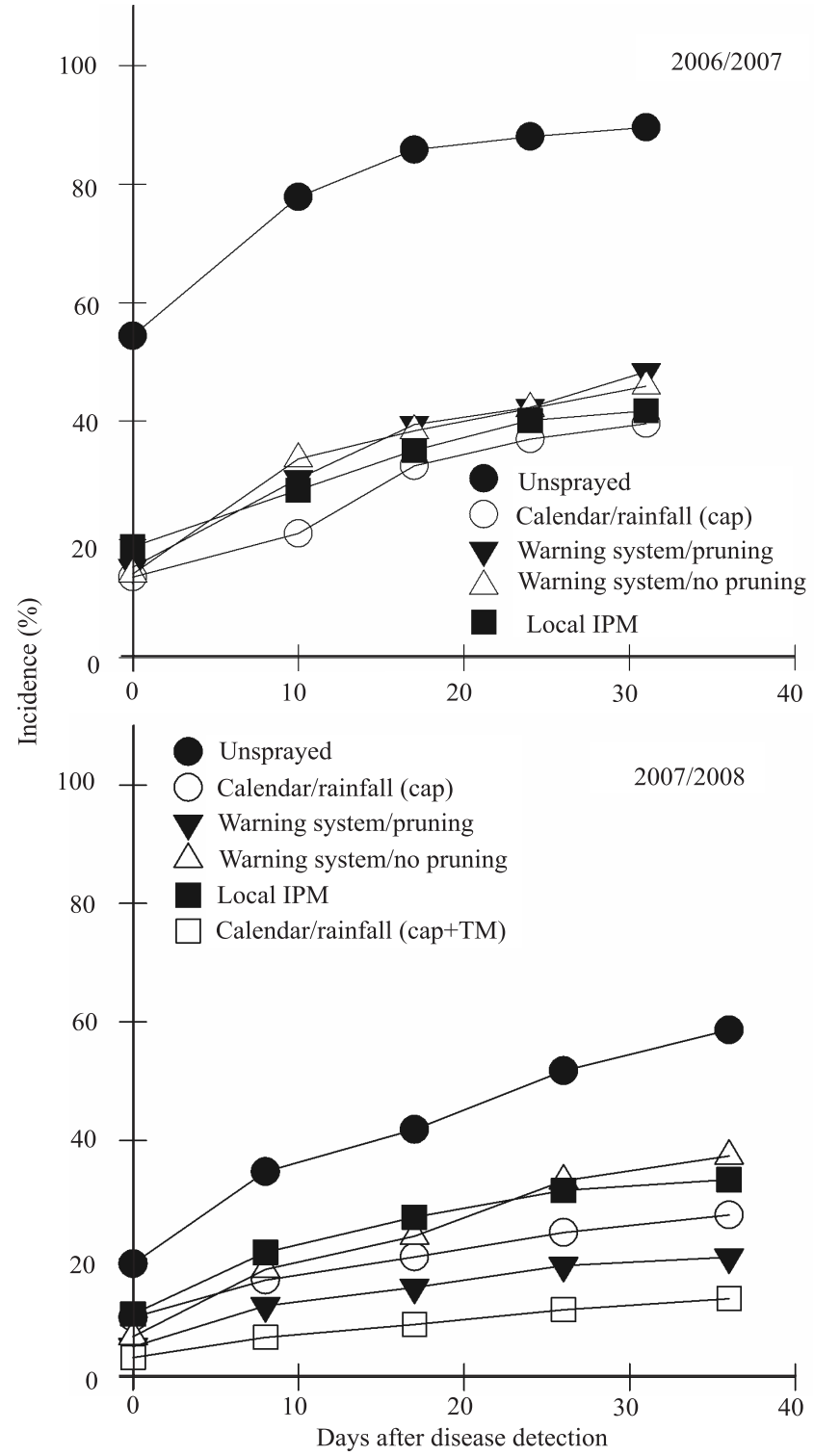

Figure 1. Temporal progress of sooty blotch and flyspeck incidence on 'Fuji' in 2006/2007 and 2007/2008 growing seasons, for the following treatments: unsprayed, no fungicide; calendar/rainfall (cap), application of captan plus Ag-Bem every 14 days or after accumulation of $50 \mathrm{~mm}$ of rain, whichever occurred first; calendar/rainfall $(\mathrm{cap}+\mathrm{tm})$, same as previous, but using thiophanate-methyl plus captan; warning system/pruning, modified BrownSutton-Hartmann system - first spray after 175-hour leaf wetness duration (LWD) threshold, reached after the 15 th day after petal fall, and further sprays delayed until a following LWD threshold was reached - and summer pruning; warning system/no pruning, same as previous, but without summer pruning, captan, $120 \mathrm{~g}$ a.i., thiophanatemethyl, $49 \mathrm{~g}$ a.i; local IPM, grower's decision based on the integrated pest management (IPM) rules and on a local disease warning system for fruit rots. 
plots, SBFS incidence (percentage of fruit with signs) in these plots was 58 and $20 \%$ in the $2006 / 2007$ and 2007/2008 seasons, respectively.

The monomolecular model described the disease temporal progress best in all treatments. The higher values for both model parameters and AUDPC data suggest that more favorable conditions for epidemics occurred in the first year (Table 2).

Sooty blotch and flyspeck progress curves with patterns similar to those observed in our study were previously reported by Trapman (2006), who studied the disease in organic production systems in the Netherlands. Monomolecular models are usually fitted to disease progress data of monocyclic diseases, in which disease progress is a function of initial inoculum (Madden et al., 2007). However, the monomolecular model has also a good fit for diseases of relatively long and variable incubation period, typical of those of quiescent infections (Bergamin Filho \& Amorim, 2002). In the case of SBFS, incubation periods longer than 50 days have been reported in Brazil (Spolti et al., 2011b) and Germany (Mayr et al., 2010), which may explain why monomolecular model described SBFS progress better than other models.
The calendar/rain-based treatment with captan in both growing seasons, and the captan + thiophanate-methyl in the second growing season required the higher number of fungicide spray, followed by the local IPM strategy targeting fruit rots, and by the warning system (Table 1).

The use of fungicides following the warning system suppressed SBFS incidence and severity with fewer fungicide sprays than the standard practices for apple growers in Southern Brazil. The warning system required 55 and $38 \%$ fewer sprays than the calendar/ rain-based protectant applications and the local IPM program, respectively.

In the 2006/2007 season, all fungicide treatments were equally effective in reducing SBFS incidence (Table 2), which was reduced by $60 \%$ in comparison to the unsprayed check. In the second year, fungicide treatments varied significantly in suppressing the disease, and all spray treatments also differed significantly from the unsprayed check. Incidence of SBFS was the lowest for captan plus thiophanate-methyl following a calendar-based spray program or the warning system plus summer pruning.

Table 2. Parameters of a monomolecular model fitted to sooty blotch and flyspeck incidence over time and the respective area under disease progress curve (AUDPC), assessed in 2006/2007 and 2007/2008 seasons, at a 'Fuji' apple orchard ${ }^{(1)}$.

\begin{tabular}{|c|c|c|c|c|}
\hline \multirow[t]{2}{*}{ Treatment $^{(2)}$} & \multicolumn{4}{|c|}{ Parameters of the model and progress curve } \\
\hline & $\mathrm{y}_{0}$ & $\mathrm{r}$ & Ymax & AUDPC \\
\hline & \multicolumn{4}{|c|}{$2006 / 2007$ season } \\
\hline Unsprayed & $1.208 \mathrm{~A}$ & $0.058 \mathrm{~A}$ & 75.37A & $2,463 \mathrm{~A}$ \\
\hline Local IPM & $0.228 \mathrm{~B}$ & $0.012 \mathrm{~B}$ & 31.13B & 960B \\
\hline Calendar/rainfall (cap) & $0.132 \mathrm{~B}$ & $0.014 \mathrm{~B}$ & $35.08 \mathrm{~B}$ & $1,020 \mathrm{~B}$ \\
\hline Warning system/pruning & $0.033 \mathrm{~B}$ & $0.028 \mathrm{~B}$ & 33.99B & $1,023 \mathrm{~B}$ \\
\hline Warning system/no pruning & $0.224 \mathrm{~B}$ & $0.015 \mathrm{~B}$ & $33.70 \mathrm{~B}$ & $1,032 \mathrm{~B}$ \\
\hline LSD & 0.211 & 0.017 & 10.35 & 205 \\
\hline Treatment & \multicolumn{4}{|c|}{$2007 / 2008$ season } \\
\hline Unsprayed & $0.237 \mathrm{~A}$ & $0.020 \mathrm{~A}$ & $58.63 \mathrm{~A}$ & $1,333 \mathrm{~A}$ \\
\hline Local IPM & $0.153 \mathrm{~B}$ & $0.009 \mathrm{BC}$ & $33.35 \mathrm{BC}$ & $410 \mathrm{~B}$ \\
\hline Calendar/rainfal (cap) & $0.121 \mathrm{BC}$ & $0.006 \mathrm{BC}$ & $27.37 \mathrm{BC}$ & 343B \\
\hline Calendar/rainfall $(\mathrm{cap}+\mathrm{tm})$ & $0.040 \mathrm{D}$ & $0.003 \mathrm{C}$ & $13.23 \mathrm{D}$ & $119 \mathrm{C}$ \\
\hline Warning system /pruning & $0.074 \mathrm{CD}$ & $0.004 \mathrm{C}$ & $20.23 \mathrm{CD}$ & $139 \mathrm{C}$ \\
\hline Warning system /no pruning & $0.088 \mathrm{BCD}$ & $0.011 \mathrm{~B}$ & $37.35 \mathrm{~B}$ & $465 \mathrm{~B}$ \\
\hline LSD & 0.072 & 0.006 & 13.92 & 135 \\
\hline
\end{tabular}

${ }^{(1)}$ Means followed by equal letters, in columns, do not differ by LSD-Fisher test, at $5 \%$ probability. ${ }^{(2)}$ Unsprayed, no fungicide; local IPM, grower`s decision based on the integrated pest management (IPM) rules and on a local disease warning system for fruit rots; calendar/rainfall (cap), application of captan plus Ag-Bem every 14 days or after accumulation of $50 \mathrm{~mm}$ of rain, whichever occurred first; calendar/rainfall (cap + tm), same as previous, but using thiophanate-methyl plus captan; warning system/pruning, modified Brown-Sutton-Hartmann system - first spray after 175-hour leaf wetness duration (LWD) threshold, reached after the 15th day after petal fall, and further sprays delayed until a following LWD threshold was reached - and summer pruning; warning system/no pruning, same as previous, but without summer pruning, captan, $120 \mathrm{~g}$ a.i., thiophanate-methyl, $49 \mathrm{~g}$ a.i. y0, initial inoculum; r, infection rate; Ymax, maximum incidence. 
Protectant programs using captan are known to have only fair effectiveness against SBFS, when it is not applied in mixture with other products regardless the spray interval (7 or 14 days), especially during wet seasons (Brown \& Sutton, 1986; Sutton et al., 2005). In our study, captan applied alone had some impact on SBFS because disease incidence was lower in this treatment than in the non-sprayed check in the first year. Such differences can be related to the higher dosage of captan (plus an adjuvant which may have helped to extend protection) than which is commonly used in the United States, as well as to differences in the infection levels during the first spray (Rosenberger \& Meyer, 2007).

In $2007 / 2008$ season, when environment was substantially less conducive for the disease, combining pruning with the warning system significantly improved disease control than in the previous year. For example, up to $71 \%$ of the diseased fruit from the most efficacious treatment (warning system plus pruning) showed signs only around the peduncle region.

When incidence data were analyzed separately for SBFS signs on the specific or combined fruit regions, all fungicide-treated plots in the 2006/2007 growing season showed significantly higher percentage of fruit showing signs restricted to the peduncle region than fruit from the unsprayed treatment (Figure 2). When fungicides were applied, less than $20 \%$ fruit showed signs across all three fruit regions. Contrastingly, in the $2007 / 2008$ season, both the fungicide-treated and the unsprayed plots showed similar percentage of fruit ( $\sim 50$ to $70 \%$ ) with SBFS signs restricted to the peduncle region, and less than $20 \%$ fruit showed signs in all fruit regions (Figure 2).

When SBFS severity was assessed separately by fruit region, fungicide sprays caused reduction of severity on all fruit parts, in comparison to the unsprayed treatment, in the 2006/2007 and 2007/2008 growing seasons (Figure 2). Variation in SBFS incidence by specific regions of fruit was also reported by Trapman (2004), who observed higher incidence and severity in the peduncle region or in portions that stay in contact with other fruit. In those parts of fruit surface, wetness may be prolonged and spray penetration may be limited, especially if fruit thinning is inadequate (Cooley et al., 1997).
Sooty blotch and flyspeck in Southern Brazil can be managed with fewer fungicide sprays by employing criteria which take into account the epidemiological knowledge. Although SBFS levels were successfully reduced in our work, the fact that the experimental area was left unsprayed for a relatively long period ( $>1.5$ to 2 weeks), from petal fall until accumulation of the 175-hour LWD threshold, may have contributed to a general low efficacy of all treatments, especially in the first year, when up to $40 \%$ of SBFS incidence was observed even in the most efficacious treatments. Future field trials could be designed to delay the start of the LWD-based threshold used, until an additional spray was applied, e.g., 7 to 14 days after petal fall, as is done often for SBFS warning systems in the United States (Babadoost et al., 2004; Duttweiller et al., 2008), and to decide for better options of fungicides to be used. Although thiophanate-methyl has an eradicative effect on SBFS infections (Brown \& Sutton, 1993), it is a class B carcinogenic (Paolini et al., 1999), and it also kills natural enemies (predatory mites), thus leading to a more intensive need of chemical insecticide use against phytophagous mites with evidently human health, economic and environmental risks (Alston \& Thomson, 2004).

Adapting a warning system to a new geographic area requires a careful, step-by-step approach as for development and implementation of any other disease-warning system (Babadoost et al., 2004; Duttweiler et al., 2008). Typically, the first, basic question to be answered is whether the warning system provides an acceptable control of the targeted disease(s), while requiring fewer fungicide sprays than needed for the prevailing grower practices in the new area. Accordingly, the present study reports successful results of a first phase of a warning system implementation, in which further stages should determine how the warning system can fit into the context of co-occurring diseases, and whether it makes economic sense for growers to use. In other words, once the warning system has proven itself in the full context of the crop's disease management scheme, a future and final step is to analyze the economic viability of the approach in the context of crop production. As it is, our results represent an essential step forward in the long process of validating a new management practice for reliable use by growers in Southern Brazil. 

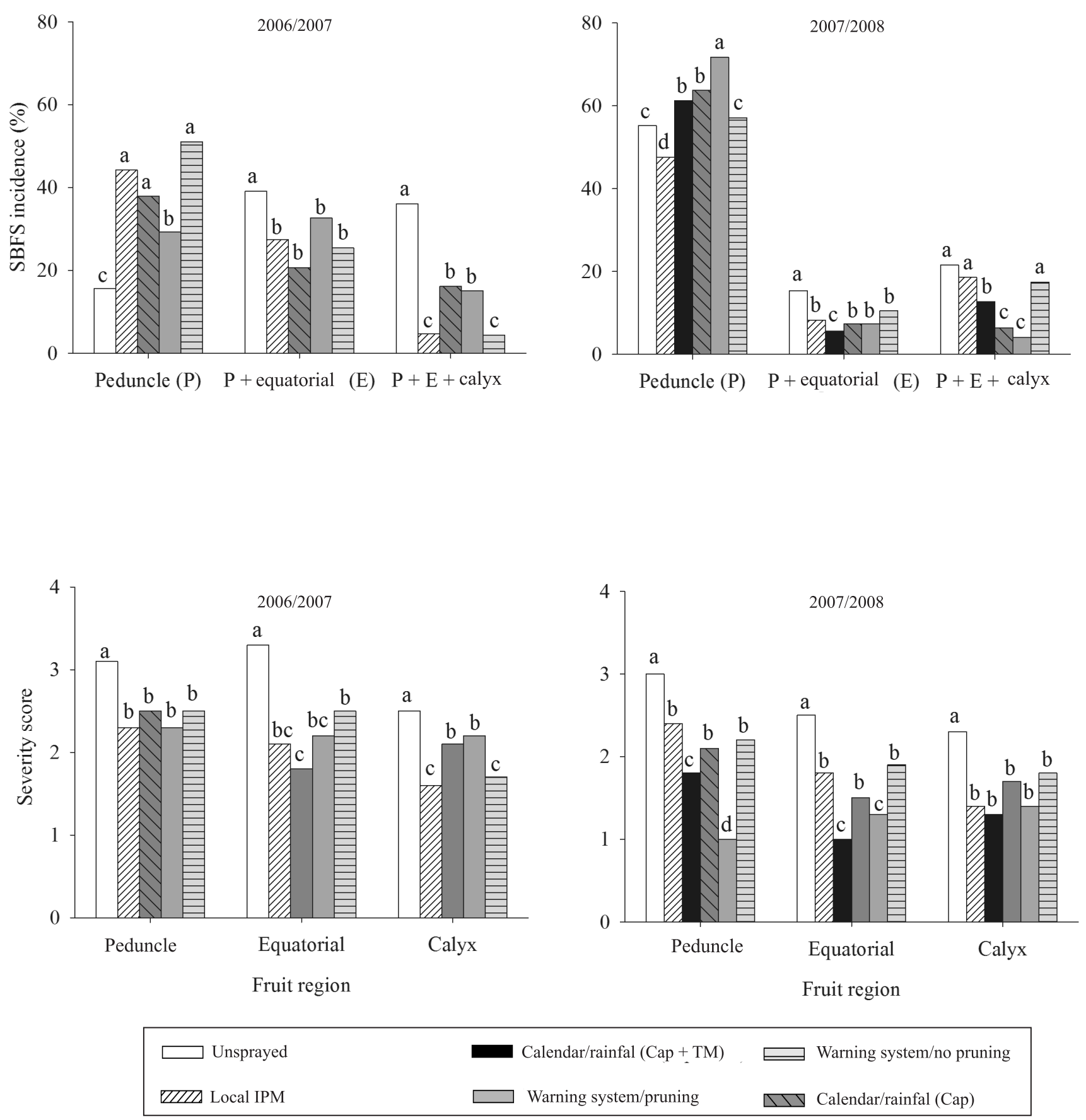

Figure 2. Sooty blotch and flyspeck (SBFS) incidence (top graphs) and severity score (bottom graphs) in 'Fuji' apples, in treatments performed during two consecutive cycles $(2006 / 2007,2007 / 2008)$. Severity score, assessed separately for fruit portion, was given based on a visual severity (\%) class interval: 1,1 to $3 \% ; 2,3$ to $6 \% ; 3,6$ to $12 \% ; 4,12$ to $25 \% ; 5,25$ to $50 \%$; and $6,>50 \%$. Means followed by iqual letters, in the comparison of treatments for each fruit region, and among regions, do not differ by LSD-Fisher test at $5 \%$ probability. Unsprayed, no fungicide application; calendar/rainfall (cap), application of captan plus Ag-Bem every 14 days or accumulation of $50 \mathrm{~mm}$ of rain; warning system/pruning, warning system and summer pruning; warning system/no pruning, warning system without summer pruning; local IPM, grower`s decision based on the integrated pest management (IPM) rules and a local disease warning system for fruit rots; calendar/rainfall $($ cap $+\mathrm{tm})$, thiophanate-methyl in combination with captan applied. 


\section{Conclusions}

1. The use of a modified version of the Brown-Sutton-Hartman system leads to a reduced number of fungicide sprays, which are as effective for the control of sooty blotch and flyspecks (SBFS) as treatments based on calendar or grower's decisions.

2. Summer pruning enhances SBFS control efficacy by reducing severity of the disease in fruit parts which are less protected by the fungicides during applications.

\section{Acknowledgements}

To Coordenação de Aperfeiçoamento de Pessoal de Nível Superior and to Conselho Nacional de Desenvolvimento Científico e Tecnológico, for fellowships granted; and to Universidade Federal do Rio Grande do Sul, Programa de Pós-Graduação em Fitotecnia , Embrapa Uva e Vinho, and Inova Maçã Project for financial support.

\section{References}

ALSTON, D.; THOMSON, S.V. Effects of fungicide residues on the survival, fecundity, and predation of the mites Tetranychus urticae (Acari: Tetranychidae) and Galendromus occidentalis (Acari: Phytoseiidae). Journal of Economical Entomology, v.97, p.950-956, 2004.

BABADOOST, M.; MACMANUS, P.S.; HELLAND, S.N.; GLEASON, M.L. Evaluating a wetness-based warning system and reduced-risk fungicides to manage sooty blotch and flyspeck of apple. Hortechnology, v.14, p.51-57, 2004.

BATZER, J.C.; GLEASON, M.L.; HARRINGTON, T.C.; TIFFANY, L.H. Expansion of the sooty blotch and flyspeck complex on apples based on analysis of ribosomal DNA gene sequences and morphology. Mycologia, v.97, p.1268-1286, 2005.

BELDING, R.D.; SUTTON, T.B.; BLANKENSHIP, S.M.; YOUNG, E. Relationship between apple fruit epicuticular wax and growth of Peltaster fructicola and Leptodontidium elatius, two fungi that cause sooty blotch disease. Plant Disease, v.84, p.767-772, 2000.

BERGAMIN FILHO, A.; AMORIM, L. Doenças com período de incubação variável em função da fenologia do hospedeiro. Fitopatologia Brasileira, v.27, p.561-565, 2002.

BERTON, O.; MELZER, R. Sistema de alerta para o controle da sarna da macieira. Florianópolis: EMPASC, 1989. 75p.

BROWN, E.M.; SUTTON, T.B. An empirical model for predicting the first symptoms of sooty blotch and flyspeck of apples. Plant Disease, v.79, p.1165-1168, 1995.

BROWN, E.M.; SUTTON, T.B. Control of sooty blotch and flyspeck of apple with captan, mancozeb, and mancozeb combined with dinocap in dilute and concentrate applications. Plant Disease, v.70, p.281-284, 1986.

BROWN, E.M.; SUTTON, T.B. Time of infection of Gloeodes pomigena and Schizothyrium pomi on apple in North Carolina and potential control by an eradicant spray program. Plant Disease, v.77, p.451-455, 1993.

COOLEY, D.R.; GAMBLE, J.W.; AUTIO, W.R. Summer pruning as a method for reducing flyspeck disease on apple fruit. Plant Disease, v.81, p.1123-1126, 1997.

COOLEY, D.R.; LERNER, S.M.; TUTTLE, A.F. Maturation of thyriothecia of Schizothyrium pomi on the reservoir host Rubus allegheniensis. Plant Disease, v.91, p.136-141, 2007.

DÍAZARIAS, M.M.; BATZER, J.C.; HARRINGTON, T.C.; WONG, A.W.; BOST, S.C.; COOLEY, D.R.; ELLIS, M.A.; HARTMAN, J.R.; ROSENBERGER, D.A.; SUNDIN, G.W.; SUTTON, T.B.; TRAVIS, J.W.; WHEELER, M.J.; YODER, K.S.; GLEASON, M.L. Diversity and biogeography of sooty blotch and flyspeck fungi on apple in the Eastern and Midwestern United States. Phytopathology, v.100, p.345-355, 2010.

DUTTWEILER, K.B.; GLEASON, M.L.; DIXON, P.M.; SUTTON, T.B.; MCMANUS, P.S., MONTEIRO, J.E.B.A. Adaptation of an apple sooty blotch and flyspeck warning system for the Upper Midwest United States. Plant Disease, v.92, p.1215-1222, 2008.

GLEASON, M.L.; BATZER, J.C.; SUN, G.; ZHANG, R.; DÍAZ ARIAS, M.M.; SUTTON, T.B.; CROUS, P.W.; IVANOVIĆ, M.; MCMANUS, P.S.; COOLEY, D.R.; MAYR, U.; WEBER, R.W.S.; YODER, K.S.; DEL PONTE, E.M.; BIGGS, A.R.; OERTEL, B. A new view of sooty blotch and flyspeck. Plant Disease, v.95, p.368-383, 2011.

MADDEN, L.V.; HUGHES, G.; BOSCH, F. van den. The study of plant disease epidemics. St. Paul: American Phytopathological Society, 2007. 421p.

MAYR, U.; SPÄTH, S.; BUCHLEITHER, S. Sooty blotch research - a progress report. In: INTERNATIONAL CONFERENCE ON ORGANIC FRUIT GROWING, 2010, Weinsberg. Proceedings. Weinsberg: Föko, 2010. p.70-77.

OCAMB-BASU, C.M.; SUTTON, T.B.; NELSON, L.A. The effects of pruning on incidence and severity of Zygophiala jamaicensis and Gloeodes pomigena infections of apple fruit. Phytopathology, v.78, p.1004-100, 1988.

PAOLINI, M.; POZZETTI, L.; PEROCCO, P.; MAZZULLO, M.; CANTELLI-FORTI, G. Molecular non-genetic biomarkers of effect related to methyl thiophanate cocarcinogenesis: organ- and sex-specific cytochrome P450 induction in the rat. Cancer Letters, v.135, p.203-213, 1999.

PAVAN,W.;FERNANDES, J.M.C.; VALDEBENITO-SANHUEZA, R.M.; DEL PONTE, E.M.; CERVI, C.R.; DALBOSCO, J. Web-based system to true-forecast disease epidemics - Sisalert. In: COMPUTERS IN AGRICULTURE AND NATURAL RESOURCES: WORLD CONGRESS CONFERENCE, 4., 2006, Florida. Proceedings. Orlando: Asabe, 2006. p.24-26.

ROSENBERGER, D.A.; ENGLE, C.A.; MEYER, F.W. Effects of management practices and fungicides on sooty blotch and flyspeck diseases and productivity of 'Liberty' apples. Plant Disease, v.80, p.798-803, 1996. 
ROSENBERGER, D.A.; MEYR, F.M. Timing summer fungicides to control flyspeck disease on apples. New York State Horticultural, v.15, p.10-13, 2007.

SPOLTI, P.; SCHNEIDER, L.; VALDEBENITO-SANHUEZA, R.M.; BATZER, J.C.; GLEASON, M.L.; DEL PONTE, E.M. Improving sooty blotch and flyspeck severity estimation on apple fruit with the aid of standard area diagrams. European Journal of Plant Pathology, v.129, p.21-29, 2011a.

SPOLTI, P.; VALDEBENITO-SANHUEZA, R.M.; GLEASON, M.L.; DEL PONTE, E.M. Inoculum and infection dynamics of the sooty blotch and flyspeck complex of apples in Southern Brazil. Journal of Plant Pathology, v.93, p.497-501, 2011 b.

SUTTON, A.L.; SUTTON, T.B. The distribution of the mycelial types of Gloeodes pomigena on apples in North Carolina and their relationship to environmental conditions. Plant Disease, v.78, p.668-673, 1994.

SUTTON, T.; BROWN, E.; ANAS, O.; MEISTER, C.W. Efficacy of phosphorus-containing fungicides on summer diseases of apples, 2005. Fungicide Nematicide Tests, v.61, p.4, 2005.
TRAPMAN, M. A simulation program for the timing of fungicides to control sooty blotch in organic apple growing. In: ECOFRUIT: INTERNATIONAL CONFERENCE ON CULTIVATION TECHNIQUE AND PHYTOPATHOLOGICAL PROBLEMS IN ORGANIC FRUIT-GROWING, 11., 2004, Weinsberg. Proceedings. Weinsberg: Föko, 2004. p.56-66.

TRAPMAN, M. Observations on the epidemiology of sooty blotch in organic orchards in the Netherlands. In: ECOFRUIT: INTERNATIONAL CONFERENCE ON CULTIVATION TECHNIQUE AND PHYTOPATHOLOGICAL PROBLEMS IN ORGANIC FRUIT-GROWING, 12., 2006, Weinsberg. Proceedings. Weinsberg: Föko, 2006. p.125-132.

VALDEBENITO-SANHUEZA, R.M.; NACHTIGALL, G.R.; KOVALESKI, A.; SANTOS, R.S. dos; SPOLTI, P. Manual de identificação e controle de doenças, pragas e desequilíbrios nutricionais da macieira. Bento Gonçalves: Embrapa Uva e Vinho, 2008. 58p.

WILLIAMSON, S.M.; SUTTON, T.B. Sooty botch and flyspeck of apple: etiology, biology, and control. Plant Disease, v.84, p.714-724, 2000.

Received on April 20, 2011 and accepted on June 17, 2011 